\title{
$\begin{array}{r}\text { WAGENINGEN } \\ \text { UNIVERSITY \& RESEARCH } \\ \hline\end{array}$
}

\author{
Effect of saffron (Crocus sativus L.) corm provenance on its agro- \\ morphological traits and bioactive compounds \\ Ghanbari, J., Khajoei-Nejad, G., \& van Ruth, S. M.
}

This is a "Post-Print" accepted manuscript, which has been Published in "Scientia Horticulturae"

This version is distributed under a non-commercial no derivatives Creative Commons (c) (1) @ $\Theta$ (CC-BY-NC-ND) user license, which permits use, distribution, and reproduction in any medium, provided the original work is properly cited and not used for commercial purposes. Further, the restriction applies that if you remix, transform, or build upon the material, you may not distribute the modified material.

Please cite this publication as follows:

Ghanbari, J., Khajoei-Nejad, G., \& van Ruth, S. M. (2019). Effect of saffron (Crocus sativus L.) corm provenance on its agro-morphological traits and bioactive compounds. Scientia Horticulturae, 256, [108605].

https://doi.org/10.1016/j.scienta.2019.108605

You can download the published version at:

https://doi.org/10.1016/j.scienta.2019.108605 
$r$.

r)

r

rr

\title{
Effect of saffron (Crocus sativus L.) corm provenance on its agro-morphological traits and
}

\section{bioactive compounds}

\author{
Jalal Ghanbari ${ }^{\text {a,b }}$, Gholamreza Khajoei-Nejad ${ }^{\text {a,c, }}$, Saskia M. van Ruth ${ }^{\text {d,e }}$
}

${ }^{a}$ Department of Agronomy and Plant Breeding, Shahid Bahonar University, P.O. box 76169-133, Kerman, Iran

${ }^{\mathrm{b}}$ Young Researchers Society, Shahid Bahonar University of Kerman, Kerman, Iran. jalalghanbari@agr.uk.ac.ir

${ }^{\mathrm{c}}$ Research and Technology Institute of Plant Production (RTIPP), Shahid Bahonar University, Kerman, Iran.

*Corresponding author: khajoei@uk.ac.ir

${ }^{\mathrm{d}}$ Food Quality and Design Group, Wageningen University and Research, P.O. box 17, 6700 AA Wageningen, The Netherlands. saskia.vanruth@wur.nl

${ }^{\mathrm{e}}$ Institute for Global Food Security, School of Biological Sciences, Queen's University, Belfast, Northern Ireland, UK

\section{Abstract}

A three-year field study was conducted to examine the variation in agronomic performance, apo-carotenoids content, bioactive compounds and antioxidant activity of saffron corms originating from nine different regions of Iran. Significant differences were observed in flowerrelated traits, corm characteristics, picrocrocin and safranal contents, total phenolic content (TPC), total flavonoid content (TFC) and radical-scavenging activity between saffron corms of different provenance. The largest differences were observed for the flower-related traits and corm properties. Hierarchical classification of the saffron corms of different provenance resulted in three main groups. One of the three groups (provenance: Ferdows, Sarayan, and Bajestan) had high underground and above ground yield potential and also produced significantly higher picrocrocin and TFC in comparison to the other groups. In contrary the group comprising corms from Zarand, Torbat, Natanz, and Estahban were characterized by the lowest agronomic performance, TFC as well as lowest antioxidant activity. The third group, consisting of corms from Gonabad and Qaen, 
ro

ry

rV

†人

rq

$\mu$

r

r

س

$r \varepsilon \quad$ Saffron yield.

ro

m4

rV

ru

rq

$\varepsilon$

\&)

$\varepsilon r$

$\varepsilon r$

$\varepsilon \varepsilon$

$\leqslant 0$

$\leqslant 7$

\section{Introduction}

represented medium levels of agronomic-related traits, and the highest TPC and antioxidant ability. These results were further explored and confirmed by principal component analysis (PCA). PCA revealed positive relationships between corm properties on the one hand and flower number and stigma yield on the other hand. No relation between agronomic related traits and quality features was observed. Furthermore, the results indicated a positive relationship between total flavonoid content and antioxidant capacity of saffron. These results can be used for the improvement of the yield and quality as well as in programs for selection of the most suitable corms for particular production locations.

Keywords: Antioxidant activity, Apo-carotenoids, Bioactive compounds, Corm provenance,

Saffron, dry stigmas of the Crocus sativus L., is a well-known and expensive spice, which belongs to the family Iridaceae. It is traditionally used in foods as a coloring and flavoring agent due to its unique color, taste, and aroma (Gresta et al., 2008b; Melnyk et al., 2010). Nowadays, saffron is also extensively used for medicinal purposes because of the phytochemical composition of its stigmas (Melnyk et al., 2010; Siracusa et al., 2011). Considering the biological and agricultural features of saffron such as flowering in autumn, adaptability to harsh environmental conditions and low water-requirement, this valuable plant is introduced in low-input and lowrainfall farming systems (Gresta et al., 2008b; Negbi, 1999). Therefore, it is considered an interesting alternative plant in arid and semi-arid regions.

Genetic improvement through molecular plant breeding of saffron is difficult because Crocus sativus is a triploid plant which is incapable of producing seeds (Gresta et al., 2008b; Agayev et 
0.

al., 2007; Ahrazem et al., 2015). Clonal selection on the basis of agronomic performance attributes, such as flower-related traits and corm number and size, is considered a promising tool for obtaining high-yield cultivars of saffron (Agayev et al., 2007). Despite the belief that saffron used to be known as one cultivar (Ahrazem et al., 2015), Siracusa et al. (2013) separated different populations from Italy, Spain, Iran, India, and Australia based on morphological traits and phytochemical components. Moreover, different Iranian saffron populations have been grouped based on apocarotenoid contents and phenotypic traits in the study conducted by Baghalian et al. (2010).

Saffron yield is highly affected by the corm properties (Gresta et al., 2008a) and the environment in which a corm grows (Gresta et al., 2009; Baghalian et al., 2010; Siracusa et al., 2010). Furthermore, the quality of saffron entirely depends on the content and composition of the metabolites responsible for the red color, bitter taste and aroma (crocin, picrocrocin and safranal, respectively) which is influenced by environmental conditions the corms are exposed to (Gresta et al., 2009; Baghalian et al., 2010; Siracusa et al., 2010). Besides apo-carotenoids, the presence of some bioactive compounds such as phenols and flavonoids have been reported in saffron stigmas. The antioxidant activity of saffron stigmas is mainly related to the bioactive compounds such as total phenolic and total flavonoid content (Karimi et al., 2010; Baba et al., 2015).

Yield variation and quality characteristics of saffron have been described in a few studies to date (Ehsanzadeh et al., 2004; Gresta et al., 2009; Baghalian et al., 2010). Genotypic variation in flower parameters and apo-carotenoids were reported in studies on saffron corms of Italian provenance (Gresta et al., 2009; Siacusa et al., 2010) and different Iranian saffron populations (Baghalian et al., 2010; Ehsanzadeh et al., 2004). However, to the best of our knowledge no studies have focused on the differences in saffron's agro-morphological traits and bio-active compounds as a result of growing location of the corms. Therefore, the main aim of this study was to compare 
$\vee$ flower-related traits, corm properties, quality, and bioactive compounds contents as well as $v$ antioxidant power of saffron corms collected from nine different locations in the semi-arid regions vr of Iran.

Vr

$\wedge \wedge$

9.

\section{Materials and methods}

\subsection{Site description and experimental details}

A three-year field examination was carried out at the research field of Shahid Bahonar University $\left(30.1440^{\circ} \mathrm{N} ; 57.0715^{\circ} \mathrm{E}\right.$ and $1774 \mathrm{~m}$ altitude) of Kerman, Iran, during three growing seasons: 2015-2016 (first year), 2016-2017 (second year) and 2017-18 (third year). Regional meteorological records (precipitation and air temperature data) of the study site were obtained from Meteorological Laboratory of Kerman, Iran (Fig. S1). The soil texture of the study site was sandy-loam (55\% sand, $32.2 \%$ silt and $12.8 \%$ clay). The soil chemical properties were as follows: pH: 7.27; EC: $1.18 \mathrm{dS} \mathrm{m}^{-1}$; organic carbon: $0.4 \%$; CEC: $20 \mathrm{cmol}(+) \mathrm{kg}^{-1} ; \mathrm{N}: 0.053 \%$ and available P: $6.2 \mathrm{mg} \mathrm{kg}^{-1}$.

Corms were collected from nine different regions of Iran (Bajestan, Estahban, Ferdows, Gonabad, Natanz, Qaen, Sarayan, Torbate-Heydarieh and Zarand) where saffron is traditionally cultivated (Table 1). A randomized complete block design arranged in split plot with three replications was performed to evaluate differences between corms of different provenance during three growing seasons. Corms of different origin were planted in main plots. The main plots were divided into sub plots in order to evaluate the seasonal effect.

\section{Table 1}

Geographical information of the corm origins

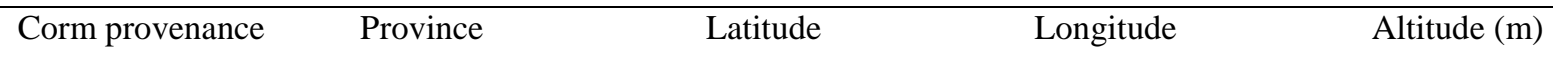




\begin{tabular}{|c|c|c|c|c|}
\hline Bajestan & Razavi Khorasan & $34^{\circ} 31^{\prime} \mathrm{N}$ & $58^{\circ} 10^{\prime} \mathrm{E}$ & 1235 \\
\hline Estahban & Fars & $29^{\circ} 07^{\prime} \mathrm{N}$ & $54^{\circ} 02^{\prime} \mathrm{E}$ & 1773 \\
\hline Ferdows & Razavi Khorasan & $34^{\circ} 01^{\prime} \mathrm{N}$ & $58^{\circ} 10^{\prime} \mathrm{E}$ & 1284 \\
\hline Gonabad & Razavi Khorasan & $34^{\circ} 20^{\prime} \mathrm{N}$ & $58^{\circ} 42^{\prime} \mathrm{E}$ & 1096 \\
\hline Natanz & Isfahan & $33^{\circ} 33^{\prime} \mathrm{N}$ & $51^{\circ} 51^{\prime} \mathrm{E}$ & 1700 \\
\hline Qaen & South Khorasan & $33^{\circ} 43^{\prime} \mathrm{N}$ & $59^{\circ} 10^{\prime} \mathrm{E}$ & 1457 \\
\hline Sarayan & South Khorasan & $33^{\circ} 51^{\prime} \mathrm{N}$ & $58^{\circ} 30^{\prime} \mathrm{E}$ & 1438 \\
\hline Torbat & Razavi Khorasan & $35^{\circ} 16^{\prime} \mathrm{N}$ & $59^{\circ} 12^{\prime} \mathrm{E}$ & 1363 \\
\hline Zarand & Kerman & $30^{\circ} 49^{\prime} \mathrm{N}$ & $56^{\circ} 34^{\prime} \mathrm{E}$ & 1666 \\
\hline
\end{tabular}

In the first growing season, after plowing, the planting bed was amended with cattle manure compost $\left(20 \mathrm{t} \mathrm{ha}^{-1}\right)$ and mixed into the upper $10 \mathrm{~cm}$. Saffron mother corms (4-8 g weight) were planted manually in $10-15 \mathrm{~cm}$ depth at 50 corms $\mathrm{m}^{-2}$ density in October 18,2015 , in each main plot $\left(12.8 \mathrm{~m}^{2}, 20 \mathrm{~cm}\right.$ apart rows and $10 \mathrm{~cm}$ within rows), and the first irrigation was applied immediately after planting.

Irrigation of the field was performed by the flood irrigation method which was scheduled based on the indigenous knowledge of producers in Iran and scientific reports (Koocheki, 2004; Kafi et al., 2018). Accordingly, four irrigations are required to achieve optimum production in saffron under field condition: first irrigation (for start of growth and flowering); second irrigation (after flowering period); third irrigation (after weeding and chemical fertilization); fourth irrigation as supplementary irrigation (at the end of growing season). After first irrigation in this experiment, five irrigation intervals were performed with some modifications on November 1, 2015 (to improve bud emergence), December 10, 2015 (after flowering period), January 26, 2016, March 4, 2016 (after weeding), April 16, 2016 (supplementary irrigation) during the first growing season. In the second growing season, due to adequate value and suitable rainfall distribution, four irrigations were applied on October 8, 2016 (first irrigation), December 7, 2016 (after flowering) 
I. V

$1 \cdot 1$

1.9

11.

111

114

111

115

110

117

118

111

119

IT.

March 5, 2017 (after weeding) and April 9, 2017 (supplementary irrigation), respectively. First irrigation at the beginning of the third growing season was performed on October 7, 2017. Other agronomic practices were done uniformly for each plot during the growth period.

\subsection{Plant sampling and measurements}

Flowering in saffron started 23, 20 and 18 days after first irrigation in the first, second and the third growing seasons, respectively. In all the three growing seasons during the flowering period, whole flowers per plot were manually collected daily (after the sunrise early in the morning), and the flower numbers (FN) were count and recoded. The harvested stigmas were separated by hand and after being air-dried under the shade (Lage and Cantrell, 2009) to constant weight, the flowerrelated traits including stigma yield (SY), stigma length (SL) and unitary stigma weight (USW), were measured. The samples were weighted on a scale (AEL-40SM, Shimadzu, Japan; $10^{-5} \mathrm{~g}$ accuracy). Daughter corms were harvested in a $1.6 \mathrm{~m}^{2}$ per plot on May 4, 2016 and April 20, 2017, in the end of first and second growing seasons, respectively. Corm-related properties such as corm number $(\mathrm{CN})$, corm yield (CY) and unitary corm weight (UCW) were determined. Dry stigmas were kept in the dark at room temperature (Siracusa et al., 2010) for the further analyses. The samples were extracted immediately in 7 days for analysis of the constituents.

\subsection{UV-vis spectrophotometry analysis}

Saffron's color, bitter taste, and aroma strength were measured by applying the ISO 3632 trade standard (ISO/TS 3632, 2003). Based on the ISO procedure, $50 \mathrm{mg}$ of powdered saffron samples were extracted in $100 \mathrm{~mL}$ distilled water and magnetically stirred for $1 \mathrm{~h}$ while being kept in dark. After filtration, the extracts were diluted $(1: 10, \mathrm{v} / \mathrm{v})$ with distilled water. Crocin, picrocrocin, and safranal were determined according to the absorbance recordings (two reads per sample) of an 
irq aqueous solution ( $\left.\mathrm{E}^{1 \%} \mathrm{w} / \mathrm{v}\right)$ at 440,257 and $330 \mathrm{~nm}$, using a SPUV-26 UV/Vis spectrophotometer

1r. (SCO Tech, Germany) with a $1 \mathrm{~cm}$ cuvette. The results were reported according to the following 1r) equation (Lage and Cantrell, 2009):

irr $E_{1 \mathrm{~cm}}^{1 \%}=(D \times 10000) /(m \times(100-H))$

מד

ITะ

ro

144

IrV

IrN

$1 \varepsilon$.

$1 \leq 1$

$1 \leqslant r$

$1 \leq \pi$

$1 \leq \varepsilon$

$1 \leq 0$

10.

Where: $D$ is the absorbance values at 257,330 and $440 \mathrm{~nm} ; m$ is the initial weight of the used sample (in grams); $H$ is the mass fraction (moisture and volatile content of the sample).

\subsection{Total phenolic and flavonoid content}

Dried-ground samples of saffron stigmas $(250 \mathrm{mg})$ were extracted by adding $10 \mathrm{~mL}$ of methanol/water $80 / 20(\mathrm{v} / \mathrm{v})$ and shaking for $8 \mathrm{~h}$ in the dark. The resulting solution was filtered and the obtained extracts were kept in the dark at a temperature of $4{ }^{\circ} \mathrm{C}$ until the further analysis.

The total phenolic content (TPC) in each sample extract was determined spectrophotometrically using the Foline-Ciocalteu's regent method (Pinelo et al., 2004). Briefly, $2.5 \mathrm{~mL}$ of ten-fold diluted Folin-Ciocalteu's reagent was added to the $0.5 \mathrm{~mL}$ sample extracts. After $5 \mathrm{~min}, 2 \mathrm{~mL}$ of $7.5 \% \mathrm{Na}_{2} \mathrm{CO}_{3}(\mathrm{w} / \mathrm{v})$ was added. The final mixture was shaken well and then incubated in a hot water bath at $45^{\circ} \mathrm{C}$ for $15 \mathrm{~min}$. The absorbance was read at $765 \mathrm{~nm}$ (against a blank) using a SPUV-26 UV/Vis spectrophotometer (SCO Tech, Germany). The TPC was expressed as mg/g of gallic acid equivalent per gram dry weight (mg GAE/g DW).

The aluminum chloride colorimetric assay was applied to quantify the total flavonoid content (TFC) as described by Tohidi et al. (2017). In summary, $0.5 \mathrm{~mL}$ of the extract was added to 0.3 $\mathrm{mL} \mathrm{NaNO}_{2} 5 \%(\mathrm{w} / \mathrm{v})$ and incubated for $5 \mathrm{~min}$ at room temperature. Afterwards, $0.6 \mathrm{~mL} \mathrm{AlCl}_{3}$ $10 \%(w / v)$ and then $2 \mathrm{~mL} \mathrm{NaOH} 1 \mathrm{M}$ were added. Finally, distilled water was added until the total volume was $10 \mathrm{~mL}$. The absorbance of the final mixture was measured at $510 \mathrm{~nm}$. A calibration curve was established using different quercetin concentrations and their corresponding absorbance 
104 lor QE/g DW).

loะ 2.5. Antioxidant activity

107

$10 \mathrm{~V}$

101

109

17.

171

174

174

$17 \varepsilon$

170

177

178

171

179

IV.

$|V|$

IVT

\section{2.5.1. DPPH radical-scavenging activity} based on linear regression analysis.

Inhibition $(\%)=\left[\left(A_{\text {Control }}-A_{\text {Sample }}\right) / A_{\text {Control }}\right] \times 100$ absorbance values of the control.

\subsubsection{Reducing power ability}

values. Total flavonoid content was reported as mg quercetin equivalents per gram dry weight (mg

The antioxidant activity was performed using the DPPH (2,2-diphenyl-1-picrylhydrazyl) method as described in Parejo et al. (2003). Briefly, $1.5 \mathrm{~mL}$ of $0.05 \mathrm{mM}$ methanolic DPPH solution was added to $0.75 \mathrm{~mL}$ of different concentrations $(50,100$ and $300 \mathrm{ppm})$ of the extract. The discoloration of the purple color was read at $517 \mathrm{~nm}$ after 20 minutes of incubation against the blank. The same concentrations of ascorbic acid were used as a positive standard. Methanol and DPPH were also used as a control of the assay. After calculation of DPPH inhibition percentage according to the equation 1, the decolorization was plotted against the sample concentration to determine the amount of sample required to $50 \%$ inhibitory concentration $\left(\mathrm{IC}_{50}\right)$ of $\mathrm{DPPH}$ radicals

Where $A_{\text {Sample }}$ is the absorbance values of the plant extract/ascorbic acid and $A_{\text {Control }}$ is the

The reducing power ability was determined as described in Tohidi et al. (2017). According to this method, $2.5 \mathrm{~mL}$ of different concentrations (50, 100, and $300 \mathrm{ppm}$ ) of methanolic extract/ascorbic acid (standard antioxidant of the assay) were mixed with $2.5 \mathrm{~mL}$ of sodium phosphate buffer $(0.2 \mathrm{M}, \mathrm{pH} 6.6)$ and $2.5 \mathrm{~mL}$ of $1 \%$ potassium ferricyanide $\left[\mathrm{K}_{3} \mathrm{Fe}(\mathrm{CN})_{6}\right]$. The 
IVT

IV

IVo

IVT

IVV

IVA

189

11.

resulting mixture was incubated at $50{ }^{\circ} \mathrm{C}$ for $20 \mathrm{~min}$. Afterwards, $2.5 \mathrm{~mL}$ of trichloroacetic acid $(10 \% \mathrm{w} / \mathrm{v})$ was added and the solution was centrifuged at $3000 \mathrm{rpm}$ for $10 \mathrm{~min} .2 .5 \mathrm{~mL}$ of distilled water and $0.5 \mathrm{~mL}$ of $0.1 \%$ ferric chloride were added to $2.5 \mathrm{~mL}$ of the supernatant obtained by centrifugation. Finally, the absorbance was measured at $700 \mathrm{~nm}$ against a blank of $80 \%$ methanol. Increased absorbance indicates the greater ability of a sample to reduce $\mathrm{Fe}^{3+}$ to $\mathrm{Fe}^{2+}$.

\subsection{Statistical analysis}

Collected data were subjected to analysis of variance (ANOVA) followed by the Least Significant Difference test (LSD; $P<0.05$ probability level) using SAS software version 9.1 (SAS, Cary, NC, USA). To classify the studied corm provenances, hierarchical cluster analysis (HCA) according to Ward's method and principal component analysis (PCA) were performed using XLSTAT 2016 (Addinsoft, New York, NY, USA). These statistical procedures were based on the parameters that showed evident variation among the studied corm provenances.

\section{Results}

\subsection{Flower-related traits}

A highly significant $(P<0.001)$ corm provenance $\times$ year effect was determined for all the flower-related traits (Table 2). The corms of varying provenance demonstrated different performance in the three-growing seasons. For instance, corms from Ferdows present good performance in the first and the third year, and Bajestan in the second year in terms of FN and SY. Corms from Sarayan and Torbat in the first year, Qaen, Sarayan and Ferdows in the second year, and Sarayan in the third year were assigned the subsequent groups (Table 2). The lowest FN and SY were recorded for corms from Zarand, Natanz and Qaen in 2015-16, Zarand in 2016-17 and Zarand and Torbat in 2017-18. On the contrary, corms from Zarand had a greater USW across 
190 different years (on average 3.75, 4.03 and $4.27 \mathrm{mg}$, respectively). Corms from Torbat in the first

197 year and Ferdows, Sarayan and Gonabad in the second and third years presented the highest SL

I9V (Table 2).

191

$199 \quad$ Table 2

$r_{\ldots} \quad$ Interaction effects of the corm provenance $\times$ year on flower number, stigma yield, stigma length, and unitary stigma

$r \cdot 1$ weight of saffron corms of different provenance recorded during three growing seasons $(2015-16,2016-17,2017-18)$.

\begin{tabular}{|c|c|c|c|c|c|c|}
\hline \multirow[t]{2}{*}{ Corm provenance } & \multicolumn{3}{|c|}{ Flower number $\left(\mathrm{m}^{-2}\right)$} & \multicolumn{3}{|c|}{ Stigma yield $\left(\mathrm{mg} \mathrm{m}^{-2}\right)$} \\
\hline & $2015-16$ & $2016-17$ & $2017-18$ & $2015-16$ & $2016-17$ & $2017-18$ \\
\hline Bajestan & $2.29 \pm 0.07^{\mathrm{c}}$ & $34.7 \pm 1.1^{\mathrm{a}}$ & $87 \pm 1.6^{c}$ & $7.22 \pm 0.37^{\mathrm{c}}$ & $134 \pm 1.0^{\mathrm{a}}$ & $376 \pm 8.7^{\mathrm{c}}$ \\
\hline Estahban & $1.90 \pm 0.11^{\mathrm{d}}$ & $10.1 \pm 1.2^{\mathrm{e}}$ & $51 \pm 1.2^{\mathrm{e}}$ & $4.77 \pm 0.15^{\mathrm{d}}$ & $33 \pm 2.2^{\mathrm{e}}$ & $187 \pm 6.9^{\mathrm{ef}}$ \\
\hline Ferdows & $5.96 \pm 0.18^{a}$ & $29.0 \pm 1.4^{b}$ & $119 \pm 3.5^{\mathrm{a}}$ & $19.7 \pm 0.38^{\mathrm{a}}$ & $122 \pm 8.6^{\mathrm{b}}$ & $513 \pm 10.4^{\mathrm{a}}$ \\
\hline Gonabad & $2.03 \pm 0.16^{\mathrm{cd}}$ & $18.7 \pm 0.4^{\mathrm{c}}$ & $83 \pm 1.2^{\mathrm{c}}$ & $5.38 \pm 0.36^{\mathrm{d}}$ & $68 \pm 1.9^{c}$ & $360 \pm 12.2^{\mathrm{c}}$ \\
\hline Natanz & $0.78 \pm 0.08^{\mathrm{e}}$ & $14.1 \pm 0.7^{\mathrm{d}}$ & $54 \pm 0.8^{\mathrm{e}}$ & $1.81 \pm 0.17^{\mathrm{e}}$ & $58 \pm 1.0^{\mathrm{cd}}$ & $228 \pm 6.8^{\mathrm{de}}$ \\
\hline Qaen & $0.78 \pm 0.05^{\mathrm{e}}$ & $29.1 \pm 1.8^{b}$ & $63 \pm 3.7^{d}$ & $2.42 \pm 0.30^{\mathrm{e}}$ & $116 \pm 3.9^{\mathrm{b}}$ & $267 \pm 19^{d}$ \\
\hline Sarayan & $2.94 \pm 0.14^{b}$ & $29.0 \pm 1.0^{\mathrm{b}}$ & $102 \pm 7.2^{b}$ & $8.39 \pm 0.19^{b c}$ & $118 \pm 6.8^{\mathrm{b}}$ & $430 \pm 31^{b}$ \\
\hline Torbat & $2.92 \pm 0.09^{b}$ & $12.6 \pm 0.6^{\mathrm{d}}$ & $31 \pm 2.6^{f}$ & $8.98 \pm 0.36^{\mathrm{b}}$ & $49 \pm 4.5^{\mathrm{d}}$ & $129 \pm 12.2^{\mathrm{g}}$ \\
\hline Zarand & $0.50 \pm 0.17^{\mathrm{e}}$ & $7.40 \pm 0.7^{\mathrm{f}}$ & $34 \pm 1.0^{f}$ & $1.82 \pm 0.74^{\mathrm{e}}$ & $30 \pm 1.9^{\mathrm{e}}$ & $145 \pm 3.5^{\mathrm{fg}}$ \\
\hline
\end{tabular}

Sources of variation

Corm provenance $(\mathrm{CP})$

$P<0.0001$

$P<0.0001$

Year $(\mathrm{Y})$

$P<0.0001$

$P<0.0001$

$\mathrm{CP} \times \mathrm{Y}$

$P<0.0001$

$P<0.0001$

$r \cdot r \quad$ Mean \pm standard error $(n=3)$ for each trait and corm provenance; different superscript letters in a column indicate $r \cdot r \quad$ significant differences (LSD tests, $P<0.05)$

r. $\quad$ Table 2

r.o Continued

\begin{tabular}{|c|c|c|c|c|c|}
\hline \multirow[t]{2}{*}{ Corm provenance } & \multicolumn{2}{|l|}{ Stigma length $(\mathrm{cm})$} & \multicolumn{3}{|c|}{ Unitary stigma weight (mg) } \\
\hline & $2015-16$ & $2017-18$ & $2015-16$ & 2016-17 & $2017-18$ \\
\hline
\end{tabular}




\begin{tabular}{lcccccc}
\hline Bajestan & $1.56 \pm 0.048^{\mathrm{h}}$ & $2.11 \pm 0.034^{\mathrm{d}}$ & $2.33 \pm 0.028^{\mathrm{ab}}$ & $3.20 \pm 0.13^{\mathrm{gh}}$ & $3.87 \pm 0.09^{\mathrm{b}-\mathrm{e}}$ & $4.18 \pm 0.16^{\mathrm{abc}}$ \\
Estahban & $1.66 \pm 0.055^{\mathrm{h}}$ & $1.99 \pm 0.031^{\mathrm{e}}$ & $2.13 \pm 0.022^{\mathrm{d}}$ & $2.52 \pm 0.19^{\mathrm{ij}}$ & $3.35 \pm 0.19^{\mathrm{fg}}$ & $3.64 \pm 0.03^{\text {ef }}$ \\
Ferdows & $1.94 \pm 0.025^{\mathrm{ef}}$ & $2.18 \pm 0.043^{\mathrm{cd}}$ & $2.35 \pm 0.007^{\mathrm{a}}$ & $3.31 \pm 0.08^{\mathrm{fg}}$ & $4.13 \pm 0.27^{\mathrm{abc}}$ & $4.24^{\mathrm{a}} \pm 0.06^{\mathrm{a}}$ \\
Gonabad & $1.93 \pm 0.031^{\mathrm{ef}}$ & $2.15 \pm 0.064^{\mathrm{cd}}$ & $2.36 \pm 0.024^{\mathrm{a}}$ & $2.72 \pm 0.07^{\mathrm{ij}}$ & $3.61 \pm 0.05^{\text {ef }}$ & $4.32 \pm 0.09^{\mathrm{a}}$ \\
Natanz & $1.78 \pm 0.030^{\mathrm{g}}$ & $2.11 \pm 0.020^{\mathrm{d}}$ & $2.31 \pm 0.036^{\mathrm{ab}}$ & $2.39 \pm 0.03^{\mathrm{j}}$ & $4.07 \pm 0.12^{\mathrm{a}-\mathrm{d}}$ & $4.25 \pm 0.20^{\mathrm{a}}$ \\
Qaen & $1.87 \pm 0.013^{\mathrm{fg}}$ & $2.10 \pm 0.026^{\mathrm{d}}$ & $2.24 \pm 0.093^{\mathrm{bc}}$ & $3.17 \pm 0.23^{\mathrm{gh}}$ & $4.08 \pm 0.19^{\mathrm{a}-\mathrm{d}}$ & $4.16 \pm 0.05^{\mathrm{abc}}$ \\
Sarayan & $1.90 \pm 0.057^{\mathrm{ef}}$ & $2.15 \pm 0.049^{\mathrm{cd}}$ & $2.38 \pm 0.028^{\mathrm{a}}$ & $2.86 \pm 0.12^{\mathrm{hi}}$ & $4.04 \pm 0.09^{\mathrm{a}-\mathrm{d}}$ & $4.22 \pm 0.01^{\mathrm{ab}}$ \\
Torbat & $2.11 \pm 0.021^{\mathrm{d}}$ & $2.11 \pm 0.034^{\mathrm{d}}$ & $2.30 \pm 0.019^{\mathrm{ab}}$ & $3.11 \pm 0.07^{\mathrm{gh}}$ & $3.85 \pm 0.18^{\mathrm{cde}}$ & $4.07 \pm 0.04^{\mathrm{a}-\mathrm{d}}$ \\
Zarand & $1.92 \pm 0.005^{\mathrm{ef}}$ & $2.12 \pm 0.029^{\mathrm{d}}$ & $2.30 \pm 0.012^{\mathrm{ab}}$ & $3.75 \pm 0.18^{\mathrm{de}}$ & $4.03 \pm 0.17^{\mathrm{a}-\mathrm{d}}$ & $4.27 \pm 0.03^{\mathrm{a}}$
\end{tabular}

Sources of variation

Corm provenance (CP)

$P<0.0001$

$P<0.001$

Year (Y)

$P<0.0001$

$P<0.0001$

$\mathrm{CP} \times \mathrm{Y}$

$P<0.0001$

$P<0.001$

$r \cdot\urcorner \quad$ Mean \pm standard error $(n=3)$ for each trait and corm provenance; different superscript letters indicate significant

Y. $\quad$ differences (LSD tests, $P<0.05)$

\section{r.A 3.2. Corm properties}

r. 9

r.

YI

YIT

rIT

YIE

rio

YIT

rIV

Corm provenance $\times$ year interaction was statistically significant $(P<0.01)$ for $\mathrm{CN}$ and $\mathrm{CY}$ (Table 3). At the end of the first and second growing seasons, a significant difference between corms of different origins was observed for $\mathrm{CN}$. A significant enhancement in $\mathrm{CY}$ per $\mathrm{m}^{2}$ was recorded for corms from Ferdows at the end of the first growing season with no statistical significant with Bajestan and Sarayan. Zarand with lowest scores of CN and UCW, and Natanz with lowest CN produced the lowest CY in the first year (Table 3). As expected, the highest averages of $\mathrm{CN}\left(1124\right.$ corms $\left.\mathrm{m}^{-2}\right)$ were recorded for Ferdows provenance and $\mathrm{CY}\left(4.52 \mathrm{~kg} \mathrm{~m}^{-2}\right)$ measured for the corms from Ferdows and Sarayan in the second year. The corms from Sarayan (despite the lower $\mathrm{CN}$ comparing to Ferdows) presented a considerable $\mathrm{CY}\left(4.56 \mathrm{~kg} \mathrm{~m}^{-2}\right)$ in the 
YIA second year which was due to the significant increase in UCW (4.54 g). Corms from Bajestan r) ranked third (1014.6 corms $\mathrm{m}^{-2}$ and $4 \mathrm{~kg} \mathrm{~m}^{-2}$ ) in the second year (Table 3).

r. $\quad$ Highly significant $(P<0.0001)$ year and corm provenance effects were observed for UCW rr) (Fig. 1). UCW differed for the corms from different origins due to the variations in $\mathrm{CN}$ and $\mathrm{CY}$ rr (Fig. 1A and Table 3). Corms from Gonabad and Ferdows presented the highest UCW, they were rr followed by corms from Sarayan, Bajeastan, and Qaen, which did not show statistical differences r $\{$ with Ferdows. On the contrary, lowest UCW was measured for the corms from Torbat and Zarand rro (Fig. 1A). Moreover, UCW was significantly higher in the second year compared to the first year rrт $\quad(36.2 \%)$ (Fig. 1B).

Table 3

rłA Corm properties (corm number and corm yield) for saffron corms of different provenance measured at the end of the rrq first (2015-16) and second (2016-2017) growing seasons of the experiment

\begin{tabular}{|c|c|c|c|c|}
\hline \multirow[b]{2}{*}{ Corm provenance } & \multicolumn{2}{|c|}{ Corm number $\left(\mathrm{m}^{-2}\right)$} & \multicolumn{2}{|c|}{ Corm yield $\left(\mathrm{kg} \mathrm{m}^{-2}\right)$} \\
\hline & $2015-16$ & $2016-17$ & $2015-16$ & $2016-17$ \\
\hline Bajestan & $219 \pm 13.0^{a}$ & $1015 \pm 18.5^{b}$ & $0.65 \pm 0.15^{\mathrm{ab}}$ & $4.00 \pm 0.14^{b}$ \\
\hline Estahban & $218 \pm 6.3^{\mathrm{a}}$ & $879 \pm 18.2 \mathrm{~cd}$ & $0.51 \pm 0.07$ bcd & $2.71 \pm 0.10^{\mathrm{d}}$ \\
\hline Ferdows & $209 \pm 12.2^{\mathrm{a}}$ & $1125 \pm 39.6^{\mathrm{a}}$ & $0.72 \pm 0.08^{\mathrm{a}}$ & $4.52 \pm 0.06^{\mathrm{a}}$ \\
\hline Gonabad & $190 \pm 27.3 \mathrm{ab}$ & $731 \pm 12.5^{\mathrm{e}}$ & $0.49 \pm 0.04^{\mathrm{cd}}$ & $3.50 \pm 0.04^{\mathrm{c}}$ \\
\hline Natanz & $165 \pm 4.1^{b}$ & $754 \pm 19.0^{\mathrm{e}}$ & $0.38 \pm 0.07 \mathrm{de}$ & $2.77 \pm 0.06^{\mathrm{d}}$ \\
\hline Qaen & $213 \pm 7.2^{a}$ & $823 \pm 14.6^{\mathrm{d}}$ & $0.54 \pm 0.03 \mathrm{bc}$ & $3.40 \pm 0.05^{\mathrm{c}}$ \\
\hline Sarayan & $221 \pm 12.8^{\text {a }}$ & $1019 \pm 47.7^{b}$ & $0.60 \pm 0.06 \mathrm{abc}$ & $4.56 \pm 0.18^{\mathrm{a}}$ \\
\hline Torbat & $211 \pm 8.9^{\mathrm{a}}$ & $897 \pm 32.5^{c}$ & $0.47 \pm 0.09^{\mathrm{cd}}$ & $2.17 \pm 0.05^{\mathrm{e}}$ \\
\hline Zarand & $161 \pm 10.3^{b}$ & $753 \pm 18.0^{\mathrm{e}}$ & $0.29 \pm 0.02 \mathrm{e}$ & $2.30 \pm 0.05^{\mathrm{e}}$ \\
\hline \multicolumn{5}{|l|}{ Sources of variation } \\
\hline Corm provenance $(\mathrm{CP})$ & \multicolumn{2}{|c|}{$P<0.0001$} & \multicolumn{2}{|c|}{$P<0.0001$} \\
\hline Year (Y) & \multicolumn{2}{|c|}{$P<0.0001$} & \multicolumn{2}{|c|}{$P<0.0001$} \\
\hline
\end{tabular}


$\mathrm{CP} \times \mathrm{Y} \quad P<0.0001 \quad P<0.0001$

$r$ Mean \pm standard error $(n=3)$ for each trait and corm provenance; different superscript letters in a column indicate

rMl Significant differences (LSD tests, $P<0.05$ )

rtr

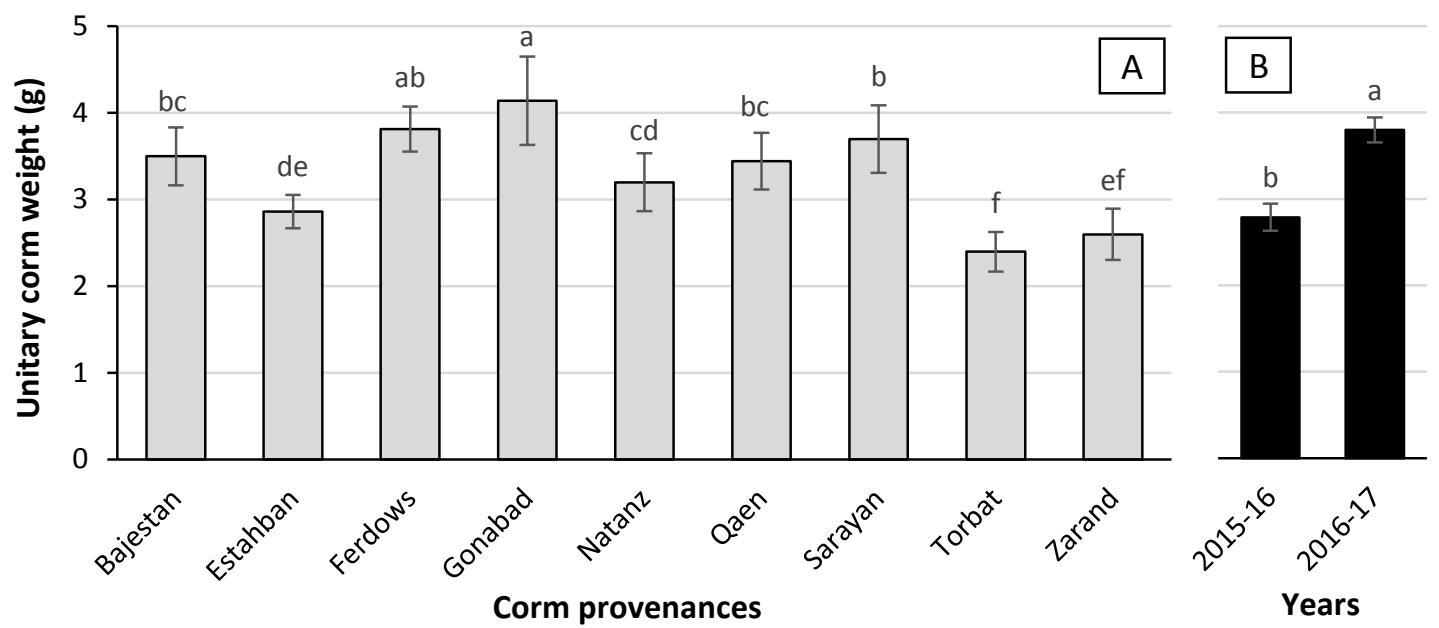

Fig. 1. Unitary corm weight of saffron corms of different provenance (A) and growing seasons (B). Mean \pm standard

rrs error (A: $n=6$ and B: $n=27$ ); different letters above columns indicate significant differences (LSD tests, $P<0.05$ ) 
rro

צry

rTV

rrN

rrq

$r \varepsilon$.

$r \leq 1$

$r \leq r$

$r \leq r$

$r \leq \varepsilon$

$r \leq 0$

$r \leq 7$

$r \leq V$

$r \leqslant 1$

$r \leq q$

ro.

rol

ror

\subsection{Crocin, picrocrocin and safranal contents}

Picrocrocin and safranal contents differed significantly between corms of different provenance $(P<0.05)$. On the contrary, the year of production as well as corm provenance $\times$ year interaction had no significant effect on these quality traits (Table 4). Picrocrocin and safranal contents (based on ISO 3632) ranged 72-86.6 and 38.5-45.3, respectively. A non-significant negative relationship $(-0.248 ; P=0.52)$ between picrocrocin and safranal contents was observed (Fig. 3B). Corms from Bajestan, produced higher picrocrocin levels followed by Ferdows, and Estahban. No differences in picrocrocin contents between corms from Ferdows and Estahban on the one hand and corms of other provenance on the other hand were observed. Corms from Estahban and Ferdows resulted also in lower safranal contents, whereas there were no significant differences between corms from Ferdows and those from the other locations. Accordingly, picrocrocin contents were relatively lower and safranal contents were higher for corms of other provenance (Table 4). Crocin content ranged from 217-220 across corms of different provenance during the two years of the experiment. This, resulted in no statistically significant differences between the experimental factors (data not shown).

\section{Table 4}

Comparison of picrocrocin and safranal contents obtained from corms of different provenance. Values are means of the second (2016-17) and third growing seasons (2017-18) of the experiment.

\begin{tabular}{lll}
\hline Corm provenance & picrocrocin $\left(\boldsymbol{E}_{\mathbf{2 5}}^{1 \%}\right)$ & safranal $\left(\boldsymbol{E}_{\mathbf{3 0}}^{\mathbf{1 \%}}\right)$ \\
\hline Bajestan & $87 \pm 2.1 \mathrm{a}$ & $43 \pm 0.9 \mathrm{a}$ \\
Estahban & $79 \pm 1.8 \mathrm{ab}$ & $39 \pm 1.4 \mathrm{~b}$ \\
Ferdows & $79 \pm 2.7 \mathrm{ab}$ & $42 \pm 1.2 \mathrm{ab}$ \\
Gonabad & $74 \pm 1.3 \mathrm{~b}$ & $44 \pm 0.7 \mathrm{a}$ \\
Natanz & $74 \pm 0.9 \mathrm{~b}$ & $44 \pm 1.1 \mathrm{a}$ \\
\hline
\end{tabular}




\begin{tabular}{lll}
\hline Qaen & $72 \pm 1.4 \mathrm{~b}$ & $42 \pm 0.9 \mathrm{a}$ \\
Sarayan & $72 \pm 1.0 \mathrm{~b}$ & $44 \pm 0.8 \mathrm{a}$ \\
Torbat & $77 \pm 2.8 \mathrm{~b}$ & $45 \pm 0.7 \mathrm{a}$ \\
Zarand & $74 \pm 0.9 \mathrm{~b}$ & $43 \pm 0.9 \mathrm{a}$
\end{tabular}

Sources of variation

$\begin{array}{clc}\text { Corm provenance }(\mathrm{CP}) & P<0.05 & P<0.05 \\ \text { Year (Y) } & \mathrm{ns} & \mathrm{ns} \\ \mathrm{CP} \times \mathrm{Y} & \mathrm{ns} & \mathrm{ns}\end{array}$

ror

ros

roo

ror

rov

roN

roq

r.

r7)

rדr

rד

rาะ

ro

rาT

rTV

rาง

\subsection{Total phenolic and flavonoid contents}

ANOVA indicated a significant corm provenance $\times$ year effect for TPC, TFC, and DPPHradical scavenging activity whereas no significant effects were determined for the reducing power ability indicator (Table 5). The total phenolic content (measured in two years) in corms of different provenance ranged between 2.96 and $6.17 \mathrm{mg} \mathrm{GAE} / \mathrm{g}$ dry weight and TFC ranged from 2.08 to $4.36 \mathrm{mg} \mathrm{QE} / \mathrm{g}$ dry weight (Table 5). Corm provenance presented a different effect in terms of the contents of bioactive compounds. For example, TPC in corms of some provenance (e.g. Ferdows, Gonabad, Natanz, Qaen, Sarayan and Torbat) showed no significant difference between the two years of the study, whereas TFC decreased significantly in the same period for these corm groups (except for Sarayan) (Table 5). TPC in corms from Bajestan and Estahban decreased significantly in 2017-18 in comparison to the previous year without any significant change in TFC. However, TPC increased significantly in Zarand during 2017-18 and TFC decreased as compared to 201617 (Table 5). 
r7q

$r v$.

YVI

rVT

TVT

TVE

rvo

rVT

TVV

TVA

rvq

rA.

rNI

rAT

rNT

YNE

rNo

rNT

rAv

TAN

rی9

The results generally indicated that corms from Zarand in 2017-18 and Qaen, Gonabad, Torbat in both years, and Estahban in 2016-17 showed higher values of TPC. Lower values of TFC were observed for corms from Natanz, Torbat, Zarand, Qaen, Ferdows and Gonabad in 2017-18. Furthermore, corms from Estahban, Bajestan and Sarayan in 2017-18 exhibited lower TPC and higher TFC which in turn resulted in the lowest and highest amounts of TPC and TFC in this study (2.96 and 3.26 and $4.02 \mathrm{mg} \mathrm{GAE} / \mathrm{g}$ dry weight and 3.11, 4.36 and $3.68 \mathrm{mg}$ QE/ g dry weight, respectively) (Table 5).

$\mathrm{IC}_{50}$ values ranged between 228 to $280 \mu \mathrm{g} / \mathrm{mL}$ in the two years of the study. Corms from Qaen showed the highest antioxidant activity with the lowest IC $_{50}$ values in 2017-18 which was closely followed by corms from Bajestan, Ferdows, Gonabad and Torbat (Table 5). For 2016-17, no significant difference was observed between the corms of the various origins, meanwhile, the antioxidant power of the corms varied in 2017-18, mainly due to variation in TPC and TFC in this year (Table 5). Similar to TPC and TFC results, strong variation between corms of different provenance was found for the DPPH-radical scavenging activity in 2017-18 (Table 5). Corms from Qaen, Bajestan, Ferdows, Gonabad and Torbat, (with the highest TPC or TFC), presented the most potent antioxidant activity, whereas the minimum antioxidant activities were observed for corms from Zarand, Natanz and Estahban (Table 5).

\section{Table 5}

Total phenolic content, total flavonoid content and DPPH-radical scavenging activity of saffron stigmas among corms of different provenance measured in the second (2016-17) and third (2017-18) growing seasons of the experiment.

\begin{tabular}{|c|c|c|c|c|c|c|}
\hline \multirow{3}{*}{ Corm provenance } & \multirow{2}{*}{\multicolumn{2}{|c|}{$\begin{array}{l}\text { Total phenolic content } \\
\text { (mg GAE/ g dry weight) }\end{array}$}} & \multirow{2}{*}{\multicolumn{2}{|c|}{$\begin{array}{l}\text { Total flavonoid content } \\
\text { (mg QE/ g dry weight) }\end{array}$}} & \multirow{2}{*}{\multicolumn{2}{|c|}{$\begin{array}{l}\text { DPPH }\left(\mathrm{IC}_{50}\right) \\
(\mu \mathrm{g} / \mathrm{mL}) \dagger\end{array}$}} \\
\hline & & & & & & \\
\hline & $2016-17$ & $2017-18$ & $2016-17$ & $2017-18$ & $2016-17$ & $2017-18$ \\
\hline Bajestan & $4.92 \pm 0.37^{\mathrm{efg}}$ & $3.26 \pm 0.26^{\mathrm{i}}$ & $3.71 \pm 0.30^{\mathrm{ab}}$ & $4.36 \pm 0.09^{\mathrm{a}}$ & $232 \pm 5.1^{\mathrm{d}}$ & $257 \pm 3.8^{b c}$ \\
\hline
\end{tabular}




\begin{tabular}{|c|c|c|c|c|c|c|}
\hline Estahban & $5.64 \pm 0.18^{\mathrm{a}-\mathrm{e}}$ & $2.96 \pm 0.34^{\mathrm{i}}$ & $3.74 \pm 0.32^{\mathrm{ab}}$ & $3.11 \pm 0.09^{\mathrm{bc}}$ & $230 \pm 4.6^{d}$ & $276 \pm 3.9^{a}$ \\
\hline Ferdows & $5.13 \pm 0.11^{\mathrm{d}-\mathrm{g}}$ & $4.91 \pm 0.26^{\mathrm{fg}}$ & $3.92 \pm 0.53^{\mathrm{a}}$ & $2.90 \pm 0.42^{\mathrm{cd}}$ & $230 \pm 2.5^{\mathrm{d}}$ & $257 \pm 1.8^{\mathrm{bc}}$ \\
\hline Gonabad & $5.34 \pm 0.21^{\mathrm{a}-\mathrm{f}}$ & $6.05 \pm 0.33^{\mathrm{ab}}$ & $3.83 \pm 0.02^{\mathrm{a}}$ & $2.95 \pm 0.42^{\mathrm{c}}$ & $237 \pm 7.5^{\mathrm{d}}$ & $257 \pm 2.4^{\mathrm{bc}}$ \\
\hline Natanz & $5.17 \pm 0.11^{\mathrm{c}-\mathrm{g}}$ & $5.23 \pm 0.16^{\mathrm{c}-\mathrm{g}}$ & $3.92 \pm 0.36^{\mathrm{a}}$ & $2.08 \pm 0.25^{\mathrm{e}}$ & $231 \pm 3.3^{\mathrm{d}}$ & $278 \pm 2.5^{\mathrm{a}}$ \\
\hline Qaen & $5.85 \pm 0.26^{\mathrm{a}-\mathrm{d}}$ & $5.66 \pm 0.65^{\mathrm{a}-\mathrm{d}}$ & $4.33 \pm 0.31^{\mathrm{a}}$ & $2.49 \pm 0.13^{\mathrm{cde}}$ & $230 \pm 2.9^{\mathrm{d}}$ & $248 \pm 1.6^{\mathrm{c}}$ \\
\hline Sarayan & $4.57 \pm 0.07^{\mathrm{gh}}$ & $4.02 \pm 0.35^{\mathrm{h}}$ & $4.05 \pm 0.28^{\mathrm{a}}$ & $3.68 \pm 0.02^{\mathrm{ab}}$ & $228 \pm 4.1^{\mathrm{d}}$ & $260 \pm 1.7^{b}$ \\
\hline Torbat & $5.48 \pm 0.20^{\mathrm{a}-\mathrm{f}}$ & $5.88 \pm 0.35^{a b c}$ & $4.19 \pm 0.10^{\mathrm{a}}$ & $2.22 \pm 0.01 \mathrm{de}$ & $232 \pm 6.4^{\mathrm{d}}$ & $256 \pm 4.1^{\mathrm{bc}}$ \\
\hline Zarand & $5.40 \pm 0.07^{\text {b-f }}$ & $6.17 \pm 0.58^{\mathrm{a}}$ & $3.78 \pm 0.34^{\mathrm{ab}}$ & $2.52 \pm 0.17^{\text {cde }}$ & $232 \pm 5.7^{\mathrm{d}}$ & $280 \pm 0.6^{\mathrm{a}}$ \\
\hline
\end{tabular}

Sources of variation

Corm provenance (CP)

$P<0.0001$

$P<0.1$

$P<0.01$

Year (Y)

$P<0.01$

$P<0.0001$

$P<0.0001$

$\mathrm{CP} \times \mathrm{Y}$

$P<0.0001$

$P<0.001$

$P<0.001$

rq. Mean \pm standard error $(n=3)$ for each trait and corm provenance; different superscript letters in a compound indicate Ү $\quad$ significant differences (LSD tests, $P<0.05$ ). $†$ Ascorbic acid $\mathrm{IC}_{50}: 119.72 \mu \mathrm{g} / \mathrm{mL}$

rqr

rqu

ras

r90

rq7

rqV

rq1
The ability of different concentrations of stigma extracts to reduce $\mathrm{Fe}^{3+}$ to $\mathrm{Fe}^{2+}$ was determined using reducing power as indicator (Fig. 2). The highest amounts of TPC, TFC and antioxidant activity (as revealed by DPPH and reducing power) were observed in 2016-17 (Table 5 and Fig. 2). Besides the statistically non-significant effects of corm provenance and corm provenance $x$ year interaction, the reducing power of saffron stigmas extracts was higher in 2016-17 as compared to 2017-18 (Fig. 2). Reduction of $\mathrm{Fe}^{3+}$ of stigmas extract was considerable as compared to ascorbic acid as positive standard (Fig. 2). 


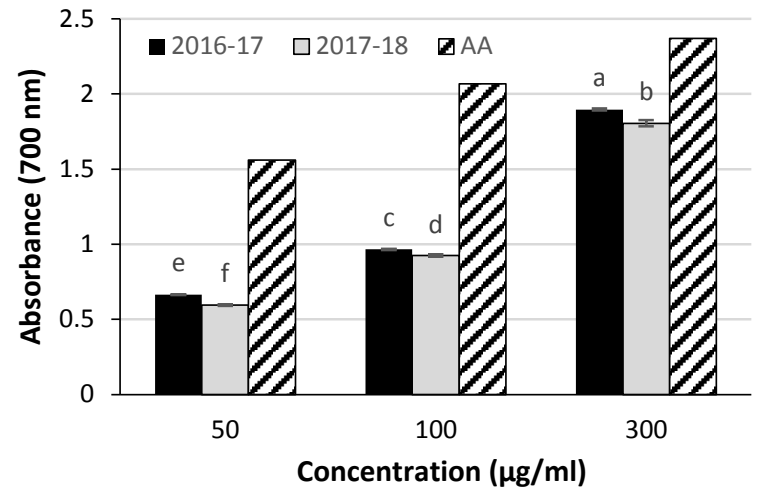

ץ.. Fig. 2. Reducing power results obtained by saffron stigmas extracts/ ascorbic acid (AA) at different concentrations.

$\Gamma \cdot 1 \quad$ Mean \pm standard error $(n=27)$; different letters indicate significant differences (LSD tests, $P<0.05)$

r.r.5. HCA and PCA analyses

$r \cdot \varepsilon \quad$ Similarities in the characteristics of corms of various provenance were examined by HCA r.o which resulted in three main groups (Fig. 3A). Cluster 1 contained corms from Ferdows, Bajestan, $r \cdot \tau$ and Sarayan and they showed the greatest mean flower-related traits, corm characteristics, high $r \cdot v$ content of flavonoids and picrocrocin, intermediate antioxidant activity and low amounts of TPC.

$r \cdot \wedge$ Contrary to the first cluster, the second cluster which included corms from Estahban, Natanz,

$r \cdot 9$ Torbat and Zarand, presented the lowest average of flower-related traits, CY and UCW, ґ. intermediate TPC and picrocrocin and the lowest TFC and antioxidant capacity. The third group II included the corms from Gonabad and Qaen and they presented intermediate flower-related traits, rir corm properties as well as TFC, high TPC and antioxidant power, and low picrocrocin contents.

To evaluate the relationships between the studied parameters and the growing locations of the TIS saffron corms, PCA was conducted and a two-dimensional PCA scatter plot (based on the two first rio PCs) was constructed (Fig. 3B). As depicted, the first two PCs explained $75 \%$ of total variation. 17 The first PC accounted for $49 \%$ of the total variance and is positively correlated with CY (0.982), 
riv FN (0.980) and SY (0.975). The corms from Ferdows and Sarayan present high CY, FN, and SY

TMA and consequently a high agronomic performance. A group of corms from four different locations

r19 (Natanz, Torbat, Zarand, and Estahban) with a low agronomic performance clearly presents higher

rr. $\quad$ IC $_{50}$ (lowest antioxidant power) and TPC (except Estahban which has a low TPC). Bajestan was

rr) characterized by a higher CN, TFC and picrocrocin content. PC2 accounted for $26 \%$ of the total

rr variance which positively correlated to safranal content (0.809), USW (0.834), SL (0.753) and

rr TPC (0.696). The mentioned variables correlated positively with the corms from Qaen and

rrs Gonabad that presented a high content of safranal and TPC as well as high antioxidant power (Low

rro $\mathrm{IC}_{50}$ ), and an intermediate agronomic performance (Fig. 3B).
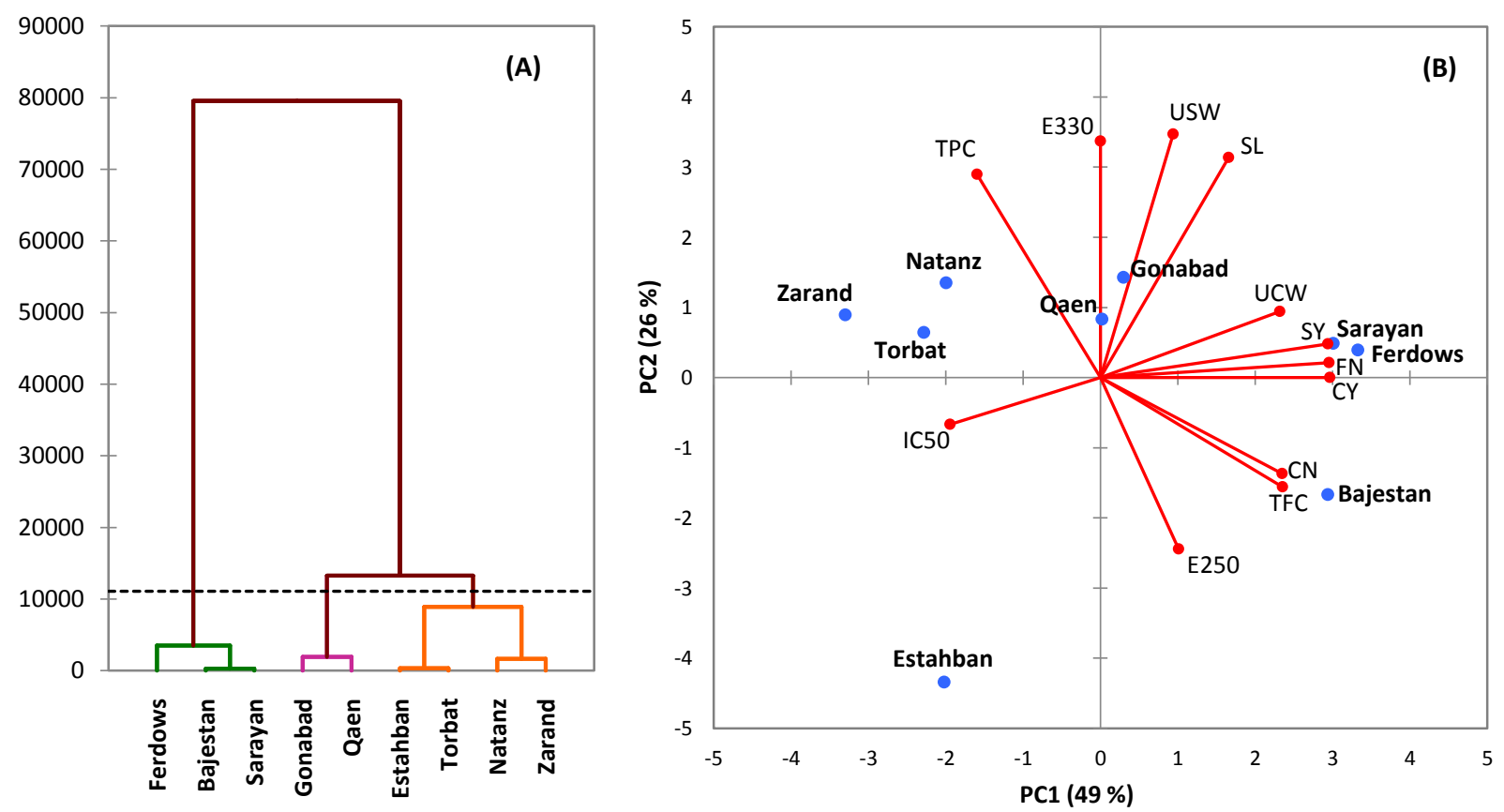

Fig. 3. Grouping of the studied corm provenance using hierarchical cluster (A) and principal component analyses (B).

rYv FN: flower number: SY: stigma yield; SL: stigma length; CN: corm number; CY: corm yield; UCW: unitary corm

rYA weight; E257: picrocrocin; E330: safranal; TPC: total phenolic content; TFC: total flavonoid content; IC 50 : DPPD

r $q$ radical scavenging activity based on 50\% inhibitory concentration; PC: Principal Component 
rr.

וT

TrT

אחזי

Tז

DO

Trד

The

אחי

act

$r \varepsilon$.

$r \leqslant 1$

$r \leqslant r$

$r \leqslant r$

$r \leq \varepsilon$

$r \leqslant 0$

$r \leq 7$

$r \leq V$

$r \leqslant \wedge$

$r \leqslant 9$

ro.

rol

\section{Discussion}

\subsection{Differences between growing seasons}

This experiment clearly demonstrated that the largest difference in flower-related traits and corm properties were found between the growing seasons (years). The annual increase in $\mathrm{CN}$ and UCW and thereby the increase in CY, significantly influenced FN and SY per unit area. FN and SY per unit area were approximately 9 and 12 times higher in 2016-17 compared to 2015-16, respectively. These two parameters were also 3.4 and 3.6 times higher in 2017-18 than in 201617, respectively. Saffron is a perennial crop which is propagated through corms (Kumar et al., 2009). During the corms-formation in the first growing season, new daughter corms will be produced and grow, which results in an increment in flower production in the next year (Amiri, 2008; Gresta et al., 2008a; de Juan et al., 2009; Kumar et al., 2009). Although not immediately increasing yields, they are important for future production. These relationships are also clearly visualized in the PCA (Fig. 3B) which confirms the positive associations between corm properties and flower-related traits. These results are in agreement with Lage and Cantrell (2009) findings. Whereas the quality parameters were not affected by the growing seasons, the highest antioxidant ability (as revealed by both DPPH-radical scavenging activity and reducing power) was measured in 2016-17. This is due to higher total phenolic and flavonoid compound contents.

\subsection{Interaction of corm provenance and growing season}

Different effects of the corm provenance over the three growing seasons were observed and may be due to their different reaction to sowing date and environmental conditions during the dormancy period in the new cultivation region (Amirnia et al., 2013; Babaei et al., 2014). In addition to producing an extended root network which increases the nutrient uptake, stronger 
ror

ror

ros

roo

ror

rov

ron

roq

ז.

एา

rT

זד

צ

ryo

צד

rTV

r4ר

rา9

rv.

rv

rVY

rVT

rV

corms also lead to an increase in daughter corm number and weight that resulted in production of more flowers in the next year (Koocheki and Seyyedi, 2015). In addition to the corm-related properties, different responses of corms of different origin, can also be attributed to the flower buds initiation time and the environmental conditions during dormancy which may make differences in the buds emergence (Behdani et al., 2016). Strong bud emergence positively affects seedling establishment and improves growth and development of saffron plant during the first growing season (Ghanbari and Khajoei-Nejad, 2018). Therefore, it potentially increases the flower production and stigma yield in the next growing season (Gresta et al., 2008a; de Juan et al., 2009). Corm provenance groups with highest corm yields produce the highest flower-related traits in next flowering season as discussed in section 4.1. Selection of the corms that are fully adapted to the environmental conditions of a certain location is an important strategy to attain higher yields at new cultivation areas (Agayev et al., 2009; Baghalian et al., 2010; Amirnia et al., 2013). Variations in morphological features among corms of different provenance has also been reported by other authors (Ehsanzadeh et al., 2004; Baghalian et al., 2010; Siracusa et al., 2010; Amirnia et al., 2013; Siracusa et al., 2013).

\subsection{Differences in quality attributes due to corm provenance}

Saffron quality greatly depends upon the variety and the growing conditions (Ehsanzadeh et al., 2004; Baghalian et al., 2010; Lage and Cantrell, 2009; Gresta et al., 2009; Siracusa et al., 2010).

Furthermore, the saffron constituents can be affected by the drying process (Carmona et al., 2005; Bolandi and Ghoddusi, 2006). It has been reported that the best conditions for drying of saffron are higher temperatures in shorter times (Carmona et al., 2005). In the present study, in spite of dehydration in shade, the averages of picrocrocin, safranal and crocin ranged $72-87,39-45$ and 217-220, respectively which indicating the highest quality (Category I). The values obtained are 
rvo in agreement with the ranges reported by Lage and Cantrell (2009) who cultivated saffron corms

rvч in different environments. They quantified the crocin and safranal values 117-350 and 36-50,

rVY respectively, in saffron stigmas dried in shade. The values of picrocrocin and crocin in saffron

r $\vee$ stigmas in corms from different origins and thus cultivated under various environmental conditions

rVq ranged 52-78 and 152-200, respectively (Gresta et al., 2009).

rA. Variability of apo-carotenoids content in corms of different provenance could be partially

rN attributed to the differences between clones (in terms of yield-superiority and clonal adaptation)

rer which may affect the quantity and quality of saffron (Baghalian et al., 2010; Agayev et al., 2009).

rAr Corms from Bajestan and Ferdows resulted in high CY, they presented also higher picrocrocin

r^乏 contents. Therefore, the clonal selection of corms that are suitable for defined environmental

r co conditions can help to attain higher quality saffron (Baghalian et al., 2010; Agayev et al., 2009).

rAт Stronger corms produce a more extensive network of roots and thereby the absorption of mineral

rNY nutrients is likely to increase (Koocheki and Seyyedi, 2015). The latter affects metabolic pathways

rA^ that results in higher amounts of secondary metabolites (Baghalian et al., 2010; Scheible et al.,

rA9 2004). The differences in quality characters of Iranian saffron populations were evaluated and

rq. reported in previous studies (Ehsanzadeh et al., 2004; Baghalian et al., 2010). Additionally,

५q) Siracusa et al. (2013) distinguished different saffron populations from Italy, Spain, Iran, India, and

rar Australia based on apocarotenoids contents.

rar Biosynthesis of apo-carotenoids in saffron is still not fully understood, however, it is well-

rq documented that picrocrocin decomposition during the drying procedure of saffron stigmas gives

r9o rise to the production of safranal (Maggi et al., 2010). Therefore, a negative relationship between

५१ч picrocrocin and safranal contents is expected. 
rav

rq1

एqq

$\varepsilon$

$\{\cdot 1$

$\varepsilon \cdot r$

$\varepsilon \cdot r$

$\varepsilon \cdot \varepsilon$

$\varepsilon .0$

$\varepsilon .7$

$\varepsilon \cdot V$

$\varepsilon \cdot 1$

$\varepsilon . q$

$\Sigma 1$.

ह1।

हा

हा

ะ)

\&10

ร17

\&1V

§1

4.4. Differences in TPC, TFC and antioxidant activity due to the interaction of corm provenance and growing season

Measured TPC, TFC, and IC50 values (2.96-6.17 mg GAE/g DW and 2.08-4.36 mg QE/g DW, and 228-280 $\mu \mathrm{g} / \mathrm{mL}$, respectively) in this study are in agreement with Baba et al. (2015) and Karimi et al. (2010) in saffron stigmas extracted by different solvents.

The observed differences between the corms of different provenance in the three growing seasons for antioxidant ability can be mainly attributed to the variation in bioactive components. These results suggested that the extracts with higher TPC and TFC had stronger antioxidant activity, which was also confirmed by Baba et al. (2015) and Karimi et al. (2010). The stronger correlation between TFC and antioxidant capacity in this experiment (Fig. 3B) indicates that the presence of flavonoid content was more responsible for inhibition of the radicals than TPC. Besides the phenolic compounds, it has been reported that the antioxidant activities are mainly attributed to the flavonoid compounds (Agati et al., 2012; Zeka et al., 2015).

\section{Conclusions}

The obtained results point out that the growing season contributes most to the differences in agronomic-related parameters in saffron production. The results of the present study clearly indicate that the agronomic, quality and bioactive features differ substantially according to the corms of different provenance. Agronomic related traits seem to differ more across corms of different origin than other parameters. HCA and PCA analyses results evidently distinguished corms of different provenance based on the examined variables: (i) corms from Ferdows, Sarayan and Bajestan were mainly characterized by high agronomic performance as well as high picrocrocin and total flavonoid content; (ii) corms from Estahban, Natanz, Torbat and Zarand were 
§19 distinguished by low agronomic performance, low total flavonoid content and antioxidant activity

$\varepsilon \uparrow . \quad$ and (iii) corms from Gonabad and Qaen were characterized by moderate agronomic performance,

\&Y maximum TPC and the highest antioxidant power. From the agronomic point of view, lower yield

Err results in lower amounts of secondary metabolites per unit area. Therefore, one possible strategy

\& for selecting the most suitable corm for particular locations for saffron cultivation requires

$\varepsilon r \leq \quad$ simultaneous consideration of underground and aboveground agronomic performance of corms as

¿ro well as their quality-related and bioactive compound contents.

¿rฯ Acknowledgments

$\varepsilon r v \quad$ The authors are grateful for the financial support from Research and Technology Institute of ¿ł^ Plant Production (RTIPP), Shahid Bahonar University, Kerman, Iran (Project number: P900/106).

\section{¿rq References}

¿r. Agati, G., Azzarello, E., Pollastri, S., Tattini, M., 2012. Flavonoids as antioxidants in plants: \&T) Location and functional significance. Plant Sci. 196, 67-76. \&rr $\quad$ https://doi.org/10.1016/j.plantsci.2012.07.014

Agayev, Y.M., Fernandez, J.A., Zarifi, E., 2009. Clonal selection of saffron (Crocus sativus L.): $\varepsilon r \varepsilon$ the first optimistic experimental results. Euphytica 169, 81-99. \&ro $\quad$ https://doi.org/10.1007/s10681-009-9946-Z

\&rч Agayev, Y.M., Shakib, A.M., Soheilivand, S., Fathi, M., 2007. Breeding of Saffron (Crocus \&TV Sativus): Possibilities and Problems. Acta Hortic. 739, 203-207. \&r^ $\quad$ https://doi.org/10.17660/actahortic.2007.739.25 
Ahrazem, O., Rubio-Moraga, A., Nebauer, S.G., Molina, R.V., Gómez-Gómez, L., 2015. Saffron: Its Phytochemistry, Developmental Processes, and Biotechnological Prospects. J. Agric. Food. Chem. 63(40), 8751-64. https://doi.org/10.1021/acs.jafc.5b03194

Amiri, M.E., 2008. Impact of animal manures and chemical fertilizers on yield components of saffron (Crocus sativus L.). Am. Eur. J. Agric. Environ. Sci. 4, 274-279.

Amirnia, R., Bayat, M., and Gholamian, A., 2013. Influence of corm provenance and sowing dates on stigma yield and yield components in saffron (Crocus sativus L.). Turk. J. Field Crops. 18(2), 198-204.

Baba, S.A., Malik, A.H., Wani, Z.A., Mohiuddin, T., Shah, Z., Abbas, N., Ashraf, N., 2015. Phytochemical analysis and antioxidant activity of different tissue types of Crocus sativus and oxidative stress alleviating potential of saffron extract in plants, bacteria, and yeast. S. Afr. J. Bot. 99, 80-87. https://doi.org/10.1016/j.sajb.2015.03.194

Babaei, S., Talebi, M., Bahar, M., Zeinali, H., 2014. Analysis of genetic diversity among saffron (Crocus sativus) accessions from different regions of Iran as revealed by SRAP markers. Sci. Hortic. 171, 27-31. https://doi.org/10.1016/j.scienta.2014.03.033

Baghalian, K., Shabani Sheshtamand, M., Jamshidi. A.H., 2010. Genetic variation and heritability of agro-morphological and phytochemical traits in Iranian saffron (Crocus sativus L.) populations. Ind. Crops Prod. 31, 401-406. https://doi.org/10.1016/j.indcrop.2009.12.010

Behdani, M.A., Jami Al-Ahmadi, M., Fallahi, H.R., 2016. Biomass Partitioning during the Life Cycle of Saffron (Crocus sativus L.) Using Regression Models. J. Crop Sci. Biotech. 19 (1): 71-76. http://dx.doi.org/10.1007/s12892-015-0082-0 
«7. Bolandi, M., Ghoddusi, H.B., 2006. Flavour and colour changes during processing and storage of saffron (Crocus sativus L.). Dev. Food Sci. 43, 323-326. https://doi.org/10.1016/S0167$\underline{4501(06) 80077-4}$

Carmona, M., Zalacain, A., Pardo, J.E., López, E., Alvarruiz, A., Alonso, G.L., 2005. Influence of different drying and aging conditions on saffron constituents. J. Agr. Food Chem. 53(10), 3974-3979. https://doi.org/10.1021/jf0404748

de Juan, J.A., Córcoles, H.L., Muñoz, R.M., Picornell, M.R., 2009. Yield and yield components of saffron under different cropping systems. Ind. Crops Prod. 30, 212-219. https://doi.org/10.1016/j.indcrop.2009.03.011

Ehsanzadeh, P., Yadollahi A., Maibodi. A.M., 2004. Productivity, growth and quality attributes of 10 Iranian Saffron accessions under climate condition of Chahar-Mahal Bakhteyari. Acta Hortic. 650: 183-188. https://doi.org/10.17660/ActaHortic.2004.650.18

Ghanbari, J., Khajoei-Nejad, G.R., 2018. Effect of compost and combination of compost and biochar application on soil bulk density of planting bed and seedling emergence rate and early growth of saffron ecotypes. J. Saffron Agron. Tech. 19, 17-33. https://doi.org/10.22048/JSAT.2017.57414.1178

Gresta, F., Avola, G., Lombardo, G.M., Siracusa, L., Ruberto, G., 2009. Analysis of flowering, stigmas yield and qualitative traits of saffron (Crocus sativus L.) as affected by environmental conditions. Sci. Hortic. 119, 320-324. https://doi.org/10.1016/j.scienta.2008.08.008

Gresta, F., Lombardo, G.M., Siracusa, L., Ruberto, G., 2008a. Effect of mother corm dimension and sowing time on stigma yield, daughter corms and qualitative aspects of saffron (Crocus sativus L.) in a Mediterranean environment. J. Sci. Food Agric. 88, 1144-1150. https://doi.org/10.1002/jsfa.3177 
$\sum \wedge$

$\leq \Lambda \leq$

$\leqslant 10$

纟ภร

纟^V

$\varepsilon \wedge \wedge$

$\varepsilon \wedge 9$

$\leqslant q$.

Gresta, F., Lombardo, G.M., Siracusa, L., Ruberto, G., 2008b. Saffron, an alternative crop for sustainable agricultural systems. A review. Agron. Sustain. Dev. 28, 95-112. https://doi.org/10.1051/agro:2007030

ISO/TS 3632-1/2., 2003. Technical Specification. Crocus sativus L. Saffron. Ed. ISO, Geneva, Switzerland.

Kafi, M., Kamili, A.N., Husaini, A.M., Ozturk, M., Altay, V., 2018. An Expensive Spice Saffron (Crocus sativus L.): A Case Study from Kashmir, Iran, and Turkey, in: Ozturk, M., Hakeem, K., Ashraf, M., Ahmad, M. (Eds), Global Perspectives on Underutilized Crops. Springer, Cham, pp. 109-149. https://doi.org/10.1007/978-3-319-77776-4_4

Karimi, E., Oskoueian, E., Hendra, R., Jaafar, H.Z.E., 2010. Evaluation of Crocus sativus L. stigma phenolic and flavonoid compounds and its antioxidant activity. Molecules 15, 62446256. https://doi.org/10.3390/molecules15096244

Koocheki A.A., 2004. Indigenous knowledge in agriculture with particular reference to saffron production in Iran. Acta Hortic. 650, $175-182$. https://doi.org/10.17660/ActaHortic.2004.650.17

Koocheki, A., Seyyedi, S.M., 2015. Relationship between nitrogen and phosphorus use efficiency in saffron (Crocus sativus L.) as affected by mother corm size and fertilization. Ind. Crops Prod. 71, 128-137. https://doi.org/10.1016/j.indcrop.2015.03.085

Kumar, R., Singh, V., Devi, K., Sharma, M., Singh, M.K., Ahuja, P.S., 2009. State of Art of Saffron (Crocus sativus L.) Agronomy: A Comprehensive Review. Food Rev. Int. 25(1), 4485. https://doi.org/10.1080/87559120802458503

Lage, M., Cantrell, C.L., 2009. Quantification of saffron (Crocus sativus L.) metabolites crocins, picrocrocin and safranal for quality determination of the spice grown under different 
0.7

$0 . V$

0.1

0.9

01.

environmental Moroccan conditions. Sci. Hortic. 121, 366-373. https://doi.org/10.1016/j.scienta.2009.02.017

Maggi, L., Carmona, M., Zalacain, A., Kanakis, C.D., Anastasaki, E., Tarantilis, P.A., Polissiou, M.G., Alonso, G.L., 2010. Changes in saffron volatile profile according to its storage time. Food Res. Int. 43, 1329-1334. https://doi.org/10.1016/j.foodres.2010.03.025

Melnyk, J.P., Wang, S., Marcone, M.F., 2010. Chemical and biological properties of the world's most expensive spice: Saffron. Food Res. Int. 43, 1981-1989. https://doi.org/10.1016/j.foodres.2010.07.033

Negbi, M., 1999. Saffron. Crocus sativus L. Harwood Academic Publishers, Amsterdam, The Netherlands.

Parejo, I., Viladomat, F., Bastida, J., Rosas-Romero, A., Saavedra, G., Murcia, M.A., Jiménezd, A.M., Codina, C., 2003. Investigation of Bolivian plant extracts for their radical scavenging activity and antioxidant activity. Life Sci. 73, 1667-1681. https://doi.org/10.1016/S0024$\underline{3205(03) 00488-0}$

Pinelo, M., Rubilar, M., Sineiro, J., Nunez, M.J., 2004. Extraction of antioxidant phenolics from almond hulls (Prunus amygdalus) and pine sawdust (Pinus pinaster). Food Chem. 85, 267273. https://doi.org/10.1016/j.foodchem.2003.06.020

Scheible, W.R., Morcuende, R., Czechowski, T., Fritz, C., Osuna, D., Palacios-Rojas, N., Schindelasch, D., Thimm, O., Udvardi, M.K., Stitt, M., 2004. Genome-wide reprogramming of primary and secondary metabolism, protein synthesis, cellular growth processes, and the regulatory infrastructure of Arabidopsis in response to nitrogen. Plant Physiol. 136(1), 2483-99. https://doi.org/10.1104/pp.104.047019 
ors Siracusa, L., Gresta, F., Avola, G., Albertini, E., Raggi, L., Marconi, G., Lombardo G.M., Ruberto, or9 G., 2013. Agronomic, chemical and genetic variability of saffron (Crocus sativus L.) of or. different origin by LC-UV-vis-DAD and AFLP analyses. Genet. Resour. Crop Evol. 60, 711721. https://doi.org/10.1007/s10722-012-9868-9

Siracusa, L., Gresta, F., Avola, G., Lombardo, G.M., Ruberto, G., 2010. Influence of corm provenance and environmental condition on yield and apocarotenoid profiles in saffron $\begin{array}{lllllll}\text { (Crocus sativus } & \text { L.). } & \text { J. Food } & \text { Compos. }\end{array}$ https://doi.org/10.1016/j.jfca.2010.02.007

Siracusa, L., Gresta, F., Ruberto, G., 2011. Saffron (Crocus sativus L.) apocarotenoids: A review of their biomolecular features and biological activity perspectives, in: Yamaguchi, M. (Eds.), Carotenoids: Properties, Effects and Diseases, Nova Science Publishers, Inc., UK, pp. 1-33.

Tohidi, B., Rahimmalek, M., Arzani, A., 2017. Essential oil composition, total phenolic, flavonoid contents, and antioxidant activity of Thymus species collected from different regions of Iran. Food Chem. 220, 153-161. https://doi.org/10.1016/j.foodchem.2016.09.203

Zeka, K., Ruparelia, K.C., Continenza, M.A., Stagos, D., Vegliò, F., Arroo, R.R.J., 2015, Petals of Crocus sativus L. as a potential source of the antioxidants crocin and kaempferol. Fitoterapia 107, 128-134. https://doi.org/10.1016/j.fitote.2015.05.014 